\title{
Consensus
}

Volume 21

Issue 1 Women and Men in Theological Education:

Article 19

Exploring the Present, Creating the Future

5-1-1995

\section{Born of a Woman: A Bishop Rethinks the Birth of Jesus}

Peter Lisinski

Follow this and additional works at: http://scholars.wlu.ca/consensus

\section{Recommended Citation}

Lisinski, Peter (1995) "Born of a Woman: A Bishop Rethinks the Birth of Jesus," Consensus: Vol. 21 : Iss. 1 , Article 19.

Available at: http://scholars.wlu.ca/consensus/vol21/iss1/19

This Book Reviews is brought to you for free and open access by Scholars Commons @ Laurier. It has been accepted for inclusion in Consensus by an authorized editor of Scholars Commons @ Laurier. For more information, please contact scholarscommons@wlu.ca. 
rights held by biblical Israel do not belong to modern Israel" (p. 67). On the other hand he cautions that Christians cannot assume to own the biblical heritage all by themselves.

Chapter 5, "A Guiding Vision: A Call to Be Earth-keepers" concludes with March articulating a vision which sounds like strains from Isaiah 9 or 11. "Earth, God's good land, has been placed in human hands by a loving creator who desires that all live in harmony and prosperity-that is, in shalom, peace" (p. 84).

March has made a serious attempt to address the thorny issue of land in an incarnational way. He describes his method of analysis as threefold, "historical reality, biblical accounts and imagery, and theological constructs" (p. 95). The historical portions are superb; biblical material is handled sensitively. He falls short, however, in applying his thesis to injustices against Palestinians. The United States has pride of place in his list of "wealthiest industrialized nations" who "even more urgently" have the mandate to care for the land (p. 87). Does the greatest wealth imply the greatest power in making decisions about "God's land"? Also, one wearies of his constant reference to "Reformed Christians" (e.g. pp. 79, 80, 92, 94, 95).

March has written a remarkable little book. For anyone wanting to get acquainted with the inexorable complexities haunting that narrow strip of land soaked in so much human blood, this book is an excellent entry point.

John H. C. Neeb

Waterloo Lutheran Seminary

\section{Born of a Woman: A Bishop Rethinks the Birth of Jesus \\ John Shelby Spong}

San Francisco: Harper, 1992

$245 \mathrm{pp}$.

As its title suggests, Born of a Woman examines the New Testament narratives describing the birth of Jesus. Moreover, implicit in the title is the author's essential claim that Jesus' birth was originally conceived to be as normal a function of biology as any other human birth. Bishop John Shelby Spong of Newark argues that the development of the Virgin Birth dogma was motivated by the need to maintain the status quo of a patriarchal church, and has contributed substantially to the oppression of women.

From cover to cover Spong articulates his case most persuasively. He is a formidable scholar and provocative writer. For example, he caricatures the intercessions of Mary, for which many devout Christians invoke her name, 
as "pillow talk" (p. 221) and delivers a scathing assessment of Augustine's personal moral character and theology (p. 215-216). While these provide evidence of Spong's sincerity and passion for his subject, some many also be classified as hasty oversights. Consider his assertion that the Judeo- Christian "faith story began by proclaiming... that only the male bore the image of God" (p. 201). This seems an inaccurate reading of Genesis 1:27. Earlier he claims that Luke's "Gospel alone had [John] the Baptist send emissaries to Jesus to inquire" (p. 115) whether or not the latter was the expected Messiah. This is a puzzling claim in light of the parallel found in Matthew 11:2-3! How such an error could escape detection by a scholar of Spong's calibre - not to mention his proof readers, consultants and publishers - is, indeed a mystery. However, I find it somewhat reassuring that Spong is at least as fallible as the church he relentlessly-and for the most part, justifiably-criticizes. And these minor flaws hardly outweigh the far more numerous treasures this book contains.

For example, chapter 12 is a truly marvelous piece of reconstructive surgery of how Joseph influenced Jesus' concept of God as 'Father'. And the following chapter speculates about the possible marriage of Jesus and Mary Magdalene. It is ironic, however, that Spong seems to take Jesus' resurrection appearance to Mary Magdalene in John's Gospel literally in describing their relationship. Nonetheless, these two chapters are representative of the profound insights and pious devotion consistently expressed throughout.

A recurring question in the book wonders whether Mary the mother of Jesus may have been raped and what the illegitimacy of Jesus may reveal about God's magnanimous grace. It remains doubtful, however, that affirmative consensus on this issue - even if achievable - would further the cause of women's liberation which Spong champions. It seems quite conceivable, in fact, that it could result in precisely the opposite, through grotesquely distorted claims justifying rape as an instrument of God's grace.

Which raises the question about the benefit the "average pew-sitter" (p. 13) can expect to receive by reading this book. Bishop Spong suggests that the insistence on the literalism of the Bible has contributed mightily to the exodus of intelligent persons from the church. His book is a plea that these "members of the church alumni association" reconsider and "invest their lives anew in this institution" (p. xvi) to which Spong himself is so thoroughly committed. Whether his assessment is true or not, and his hope realized or not, remains to be seen. But I found this book intellectually exciting, spiritually inspiring, personally challenging and faith-affirming! I strongly recommend it to any person who takes the Bible seriously.

Peter Lisinski

Faith Evangelical Lutheran Church

Fergus, Ontario 